\title{
The language of "Ribbonmen": A CDA approach to identity construction in nineteenth-century Irish English threatening notices
}

DOI:

10.1515/jhsl-2017-1007

\section{Document Version}

Accepted author manuscript

Link to publication record in Manchester Research Explorer

Citation for published version (APA):

Van Hattum, M. (2017). The language of "Ribbonmen": A CDA approach to identity construction in nineteenthcentury Irish English threatening notices. Journal of Historical Sociolinguistics, 3(2), 241-262.

https://doi.org/10.1515/jhsl-2017-1007

\section{Published in:}

Journal of Historical Sociolinguistics

\section{Citing this paper}

Please note that where the full-text provided on Manchester Research Explorer is the Author Accepted Manuscript or Proof version this may differ from the final Published version. If citing, it is advised that you check and use the publisher's definitive version.

\section{General rights}

Copyright and moral rights for the publications made accessible in the Research Explorer are retained by the authors and/or other copyright owners and it is a condition of accessing publications that users recognise and abide by the legal requirements associated with these rights.

\section{Takedown policy}

If you believe that this document breaches copyright please refer to the University of Manchester's Takedown Procedures [http://man.ac.uk/04Y6Bo] or contact uml.scholarlycommunications@manchester.ac.uk providing relevant details, so we can investigate your claim.

\section{OPEN ACCESS}


The language of "Ribbonmen": A CDA approach to identity construction in nineteenth-century Irish English threatening notices ${ }^{1}$

\begin{abstract}
Throughout the nineteenth century, the rural midlands of Ireland suffered from agrarian violence and intimidation through threatening notices. In the minds of the authorities, these outrages were committed by members of a secret society, called the "Ribbon Society", which was deemed to be the embodiment of a nation-wide conspiracy of Irish Catholics to exterminate all Protestants in the country (Beames 1982). However, present-day historians are divided in their opinion on the existence of such a society, as for example, Garvin (1982:154), who claims that "local agrarian groups simply accepted the label wished upon them by magistrates, police and other outsiders". Thus, there is no consensus about the identity and existence of the "Ribbon Society" from an external point of view. This paper analyses how the identity of this socially marginalised group is constructed from an internal point of view through means of a CDA analysis of a collection of threatening notices written by those accused of membership of the Ribbon Society. I argue that the notices constitute a form of public discourse that is controlled by the labouring classes, and that through means of positive self and negative other representation the senders justify and legitimise their own actions and beliefs, while criminalising those of their intended targets, thus constructing an identity as defender of the labouring classes, and using the notices as a form of social protest.
\end{abstract}

Keywords: Ribbonism, threatening notices, identity construction, CDA

\title{
1. Introduction
}

In 1871 a Select Committee was appointed to investigate the nature and effect of certain unlawful combinations operating in the county Westmeath, Ireland (House of Commons 1871). In an age of agrarian violence and the establishment of the Irish Republican Brotherhood, also known as the Fenian Brotherhood, the authorities feared "a nation-wide conspiracy of Irish Catholics determined on the extermination of all Protestants" (Beames 1982:128), and the committee was instructed to inquire after the existence of such a conspiracy and to determine whether any legal measures were necessary to restore peace in this part of Ireland. The committee came to the conclusion that:

there is at present existing within the county of Westmeath and certain adjoining portions of the county of Meath and of the King's County, an unlawful combination and confederacy of a secret nature, generally known by the name of the Ribbon Society [...] That owing to the prevalence of this Society, murder and other crimes of the most serious nature have been perpetrated within the district above referred to, and that by reason partly of sympathy with the perpetrators of such crimes, and still more by the terror created by the existence and action of the Society, it has been found to be almost impossible to obtain evidence on which to bring offenders to justice [...] That this Society, originating in a desire on the part of its members to interfere in an unlawful and violent manner in matters relating to the tenure and occupation of land, has extended the sphere of its operations, and more or less prejudicially affects other relations of life [...] That the Society, besides leading directly to the perpetration of the crimes already mentioned, has infused a feeling of terror into all classes in the district, by reason of which its objects are frequently brought about, without any overt act of violence (House of Commons 1871: iii-iv)

\footnotetext{
${ }^{1}$ I gratefully acknowledge the support of the British Academy/Leverhulme Small Research Grants (SRG 132000 The language of the poor in nineteenth-century Dublin). In addition, I would like to thank the editors and the two anonymous reviewers for their constructive feedback. Any remaining errors are, of course, my own.
} 
These short extracts from the report reveal that the authorities perceived these unlawful combinations as belonging to a single organisation, using words and phrases such as confederacy, society, members, sphere of operations, and in other parts of the final report not quoted here recruits its ranks, heads of the Society, leader or organiser of the Ribbon Society. The label they used to describe this society is the Ribbon society, and its members are referred to in the report and the minutes as Ribbonmen. In addition, the extract demonstrates a discourse of criminalisation through such terms as unlawful, confederacy, murder, crimes, perpetrators, terror, bring offenders to justice, violent manner, and prejudicially. Finally, though the report mentions that sympathy for the Society was to be found, it asserts that the majority of the Westmeath population lived in fear of the Society. The societal stance towards the society was deemed to be of importance, since in an earlier draft version of the report, those who sympathised and those who lived in fear were given an equal weighting.

Though it could be argued that this perception of the Ribbon society is representative of the committee, the perception was not shared by all witnesses questioned, as evidenced by the minutes. In addition, historians are still divided on whether such a society ever existed, and if it did, what the exact nature of it was (cf. Beames 1982; Comerford 1989a; Garvin 1982; Malcolm 2002; Murray 1986; Whelehan 2012). Thus, no consensus has been reached on the nature of Westmeath "Ribbonism" in the 1860s from an external point of view, though contemporary authorities seem to have perceived it as a large-scale criminal organisation which instilled fear in the population. The aim of this paper then, is to provide a more internal point of view and investigate how the socially marginalised group of "Ribbonmen" constructed their own identity.

As mentioned in the extract, the "Ribbonmen" often did not resort to "any overt act of violence" to accomplish their goals, but made frequent use of threatening notices as a means of intimidation (Whelehan 2012:7-8). This paper will analyse 103 such notices sent from and to Westmeath and its immediate surroundings between 1860 and 1871, using a Critical Discourse Analysis (CDA) approach. CDA, and more specifically the discourse-historical approach (DHA) as proposed by Wodak (2001), has been successfully applied to the study of out-group and in-group identities during periods of unrest in the more distant past. Prentice and Hardy (2009), for example, analysed processes of empowerment and disempowerment in the Glencairn uprising in Scotland 1653, and MacLeod (2012) and MacLeod and Fennel (2012) investigated identity-construction in the 1641 depositions. ${ }^{2}$ These studies, in line with the CDA approach, used public discourse such as news books and "selected, edited and interpreted" (MacLeod and Fennel 2012: 260) witness depositions produced by elite groups to investigate their role in upholding dominant ideologies. Contrary to these previous studies, this paper uses a DHA approach to study the language used by a marginalised group of Ribbonmen, rather than elite groups and/or institutions. I argue that the notices sent by these Ribbonmen provided the labouring classes with access to, and control over, a form of public discourse. Therefore, investigating identity-construction in these notices gives us insights into the dominant ideologies that this marginalised social group was spreading within their community.

\section{Historical background}

In line with Wodak's (2001) DHA, the historical context is given much consideration, and thus this section will provide a concise account of rural life in nineteenth-century Ireland in particular with respect to agrarian outrages and the rise of "Ribbonism". In addition, the circumstances under which the threatening notices were collected are discussed. The concerns addressed in the threatening

\footnotetext{
${ }^{2}$ The 1641 depositions are a collection of testimonies from predominantly Protestant witnesses of the Irish uprising in 1641.
} 
notices mainly cover a) changes in the use of conacre land, particularly the redistribution of former conacre land as grazing land, b) high rents and evictions, and c) firing and hiring of labourers.

In the first half of the nineteenth century population rose rapidly, which caused an increase in the labour force and the demand for land. As a result, the prices of land went up, but the wages of labourers did not, causing an imbalance "between the earning of the poor cultivator and the price he was expected or forced to pay for his land" (Gibbons 2004:19). In many cases, this led to dispossession of land and home because tenants could either not afford their rent and were evicted on grounds of non-payment, or tenants could be evicted because someone else was able and willing to pay a higher rent. In addition, the population increase led to the risk of food shortages whenever crops failed, as witnessed for example by the Great Famine in the 1840 s.

Before the Great Famine, many landless labourers provided for themselves through the letting of conacre land. Conacre was a system where small plots of land were briefly let to landless labourers, usually in spring. It enabled labourers to grow their own crops, while paying for the rent in labour (Gibbons 2004). During this time, the country witnessed the start of a shift from arable to livestock farming, as the latter was less labour intensive and the price of cattle had increased substantially, while the price of grain only rose slightly, thus making livestock farming more profitable. In addition, as population plummeted due to starvation and migration because of the Great Famine in the 1840s, landowners were presented with the opportunity to consolidate land previously reserved for conacre into larger livestock farms, either through eviction or because of vacancies due to death and migration, meaning that the labouring classes lost the ability to provide for themselves (Comerford 1989: 381). Since the shift from arable to livestock farming also caused a decrease in labour demand, "[a]ny available work was fiercely sought and jealously guarded" (Gibbons 2004: 27), leading to discontent when local labourers were fired and/or labourers from different counties or countries were hired.

Disputes over land, rent and labouring conditions led to the rise of agrarian societies such as the Whiteboys, the Defenders and the Ribbon society, who on occasion committed violence in the form of murder, nocturnal intimidation by armed parties, firing at the person, destruction of property, but mainly achieved their goal through intimidation and the sending of threatening notices (Whelehan 2012). The authorities of the time tended to ascribe most outbreaks of agrarian violence in nineteenth-century Ireland to the Ribbon Society, but historians hesitate to confirm the existence of one such society and instead deem it more likely to be the work of smaller local groups (e.g. Garvin 1982). Since I am interested to see how the social group as constructed by the authorities perceived themselves, it seems appropriate to use the definition and the labels "Ribbonism", "Ribbon Society" and "Ribbonman" as prevalent in the institutional discourse of the time. The focus for this paper will be on 1860s Westmeath, because for this period and region we have access to both group-external discourse in the form of the Westmeath report, and group-internal discourse in the form of threatening notices. Thus, the "Ribbon" terms here refer to the way this marginalised group is constructed in the Westmeath report; that is, as an illegal secret society which commits itself to criminal activities in order to interfere with matters relating to the tenure and occupation of land, as well as the hiring and firing of labourers, and which consists predominantly of farm servants and daily labourers.

In addition to agrarian outrages, there was an increasing interest in nationalist ideology, particularly in the form of the Fenian Brotherhood. The movement was established by Irish Americans in the US in the 1850 s and soon spread to Ireland. It sought to establish Irish independence, initially via a plebiscite, but soon preparations for an uprising began (Comerford 1989b: 417-23). The uprising was prevented partially due to bad planning and partially due to British intervention in the form of 
suspension of Habeas Corpus in 1866 which allowed for the arrest of suspected Fenians without trial (Comerford 1989c: 438). Though the authorities had successfully prevented the uprising, they believed that many former Fenians afterwards joined the Ribbon Society, giving the society a nationalist ideology (House of Commons 1871).

As discussed in the introduction, a committee was formed in 1870 to investigate the nature of the agrarian outrages in Westmeath and determine whether any additional legislative measures were necessary to restore the peace. One of the outcomes of the report was the passing of the 1871 Protection of Life and Property in Certain Parts of Ireland Bill, also known as the 1871 Westmeath Act. This act temporarily enabled the Lord Lieutenant of Ireland to detain without trial any suspected Ribbonmen from Westmeath and its adjacent baronies, and it suspended Habeas Corpus which meant that those arrested under the Lord Lieutenant's warrant could not appeal until it was reinstated (House of Lords 1871). This allowed the authorities time to gather sufficient evidence to convict the Ribbonmen once Habeas Corpus was reinstated, since with the leaders of the Ribbon organisation detained, the local population no longer had to fear reprisals for giving information to the authorities.

In preparation for the trial, the authorities seem to have collected dozens of threatening notices and handwriting samples for comparison (van Hattum in progress a), and it is this collection that provides the source material for this paper. The collection is housed in the National Archives in Dublin, and consists of ninety-seven original notices sent from or to Westmeath and its surroundings between 1860 and 1871, most of which were also photographed and glued into a book with some annotations on suspected authors. The book also contains some photographs of handwriting samples and prison letters used for comparison. In addition to the collection, six similar notices were found in the Registered Papers of the Chief Secretary's Office and are included in the analysis as they resembled the other notices in terms of topic, date and origin. Thus, the collection of notices under investigation in this paper consists of 15,246 orthographic units ${ }^{3}$ spread across 103 notices.

It should be kept in mind that ninety-seven of the 103 notices under investigation here were compiled into a collection by the authorities in the late nineteenth century, and the precise motivations for including items in the collection remain unclear. It is possible that these were simply all the notices concerning Westmeath in the 1860s that they had in their possession at the time. Or, it could be that all the notices in the collection were indeed produced by the suspects they wanted to bring to justice under the Lord Lieutenant's warrant, but the handwritten annotations for the notices only indicate suspected authors for some notices. A final option, is that the authorities purposefully included only those notices that conformed to their perception of the Ribbon Society and justified them in their actions of suspending habeas corpus to deal with this substantial threat. Nevertheless, these notices were still produced by those suspected to be Ribbonmen themselves, and thus allow for the study of identity-construction from a group-internal point of view.

\section{The Discourse Historical Approach to Critical Discourse Analysis}

The assumptions of Critical Discourse Analysis (CDA) in general, and the Discourse Historical Approach (DHA) more specifically, provide the theoretical point of departure. From a CDA perspective, language constitutes a mode of representation that is inherently partial and ideologically biased (MacLeod 2012). There are a multitude of different ways in which an event could

\footnotetext{
${ }^{3}$ An orthographic unit refers to 'groups of graphs which the writer separated from other groups by spaces before and after' (Fairman 2007:31)
} 
be represented, and one of the aims of CDA is to uncover why the event is presented in one way and not another. CDA thus provides a useful framework for the analysis of the social representations of groups and the construction of ingroups and outgroups, that is an "us" versus "them" distinction. Through representation in public discourse, individuals and social groups have their identities constructed and their actions represented as either legitimate or illegitimate. Therefore, those who are in control of the discourse have the power to present themselves in a positive light, while representing the other in a negative light. In the case of the threatening notices, it is the Ribbonmen, rather than an elite group or institution, who have control over the discourse and have the opportunity to construct their own and their target's identities. However, since the aim of a threatening notice is generally to intimidate the addressee, it does not necessarily make sense for the senders to present themselves in a positive light, and it would thus be interesting to see if they still make use of positive-self and negative-other construction.

DHA approaches social group construction and representation in public discourse by integrating "a large quantity of available knowledge about the historical sources and the background of the social and political fields in which discursive events are embedded" (Wodak 2001: 65). The framework outlines several categories for analysing positive-self presentation and negative-other presentation including the categorization of individuals into social groups, labelling of social actors, justifications of positive or negative attributes, positioning of the speaker's point of view, and mitigation or intensification of utterances (Wodak 2001: 73). In addition, the approach relies on "content-based categories, or topoi, which are the headings under which arguments can be classified providing the common-sense reasoning on which particular arguments are based" (MacLeod 2012: 116), such as definition/name-interpretation, humanitarianism, justice, and law and right (Wodak 2001: 74).

\subsection{Corpus-assisted discourse analysis}

One of the criticisms of discourse analysis concerns the potential for researcher bias resulting from preconceived or existing notions. However, since "powerful discourses tend to be articulated repeatedly in language" (Baker 2010: 122), a corpus-assisted approach to discourse analysis allows for an additional quantitative and more objective layer to the analysis. For example, the frequency of certain words, phrases, or semantic/pragmatic domains can reveal some of the foci of the texts under investigation. WordSmith (version 6.0.0.237) was used to perform a keyword analysis and various concordance searches. For the keyword analysis, the software compared the frequency of all lexical items within the collection of threatening notices to a reference corpus to determine which words appear significantly more frequently. The reference corpus consisted of the current version of the Irish component of the corpus Letters of Artisans and the Labouring Poor (Auer et al, under construction). At the time, this corpus consisted of 123,106 orthographic units of emigrant letters, poor relief petitions, prison letters and other types of correspondence produced by the lower ranks of society in nineteenth-century Ireland.

The spelling in the threatening notices is highly variant, so to allow for an accurate frequency list, the collection was first normalised manually with VARD (2.5.4). Once the keywords list had been generated, each individual keyword was examined using the concordance tools of WordSmith to ensure that all keywords were relevant, and to analyse how the keywords were used within the context of the notices. The keywords were then grouped into semantic/pragmatic categories to reveal the most salient topoi. Since the collection of threatening notices is considered very small for a corpus-linguistic study, individual words may occur too infrequently to be identified as keywords, but groups of words that have similar functions within the texts could still reveal the presence of a particular discourse. Therefore, the notices were analysed manually to uncover any additional lexical items or morpho-syntactic patterns that could be included within the relevant topoi. 


\section{Identity construction in the threatening notices}

In this section, I will discuss the results of the keyword analysis and the manual analysis outlined above. The keyword analysis identified forty-nine keywords, which are represented in Table 1 below alongside their raw frequency count, the number of unique texts the keyword occurs in, and the loglikelihood score to indicate the keyness value. The keywords were grouped into the following semantic/pragmatic or functional categories: 1) labels for social groups, 2) warning, 3) violence, 4) justice/humanitarianism, 5) law and right. Close analysis of the keywords in context revealed that some of them could be included in multiple categories. For example, mark is included in the category warning (e.g. mark the consequence), as well as violence (e.g. I expect not to miss my mark). In these instances, each individual occurrence of the keyword was grouped into to the semantic/pragmatic categories separately according to its meaning in context. In addition, certain keywords used as labels for social groups could at the same time belong to one of the other categories; for example, tyrant is a label used for a particular social group, but also signals a discourse of justice and humanitarianism. In these instances, the keyword was included in both categories.

\begin{tabular}{|c|c|c|c|c|c|c|c|}
\hline Key word & Frequency & Texts & Keyness & Key word & Frequency & Texts & Keyness \\
\hline you & 671 & 96 & 477.85 & lands & 13 & 9 & 37.52 \\
\hline will & 280 & 93 & 186.86 & Tarlington & 8 & 8 & 36.89 \\
\hline if & 164 & 86 & 158.80 & Clooneyhige & 8 & 7 & 36.89 \\
\hline take & 87 & 58 & 142.44 & chance & 18 & 14 & 36.89 \\
\hline land & 64 & 38 & 122.38 & put & 29 & 21 & 36.41 \\
\hline warning & 25 & 16 & 115.32 & hold & 15 & 10 & 36.06 \\
\hline give & 85 & 54 & 112.81 & caution & 10 & 9 & 35.72 \\
\hline don't & 61 & 80 & 96.06 & yous & 25 & 11 & 34.19 \\
\hline mark & 24 & 19 & 88.58 & get & 60 & 44 & 32.55 \\
\hline Rory & 17 & 15 & 78.41 & any & 61 & 42 & 32.17 \\
\hline public & 19 & 13 & 64.12 & tenants & 10 & 8 & 30.21 \\
\hline powder & 12 & 12 & 55.34 & before & 43 & 33 & 30.21 \\
\hline man & 54 & 36 & 54.17 & life & 15 & 11 & 29.70 \\
\hline sure & 33 & 30 & 53.65 & taking & 15 & 11 & 29.60 \\
\hline or & 109 & 56 & 51.17 & same & 41 & 30 & 27.70 \\
\hline be & 176 & 75 & 50.92 & tyrant & 6 & 6 & 27.67 \\
\hline doom & 11 & 8 & 50.73 & valuation & 6 & 5 & 27.67 \\
\hline shot & 15 & 13 & 47.74 & bullet & 6 & 6 & 27.67 \\
\hline oppression & 14 & 11 & 46.34 & Sir & 33 & 28 & 26.83 \\
\hline up & 58 & 41 & 46.19 & tenant & 7 & 6 & 26.46 \\
\hline tyranny & 10 & 6 & 46.12 & $\mathrm{Mr}$ & 48 & 34 & 25.59 \\
\hline as & 199 & 69 & 45.09 & so & 89 & 47 & 25.52 \\
\hline your & 208 & 78 & 44.61 & hill & 13 & 11 & 24.43 \\
\hline do & 87 & 53 & 42.00 & laws & 9 & 6 & 24.31 \\
\hline captain & 12 & 12 & 38.19 & won't & 19 & 18 & 21.69 \\
\hline
\end{tabular}

Table 1 Overview of all keywords found in the threatening notices

Since the labels and attributes are ascribed to different social groups, the next step is to identify the different social groups constructed in the notices. As I am interested in how the social group labelled Ribbonmen by the authorities constructed their own identity, and since the authorities believed these Ribbonmen to be responsible for the sending of all threatening notices, the authors of the 
notices will be classified as members of the Ribbon Society, regardless of whether they belonged to any such social group in reality.

Based on the list of keywords, it is tempting to group the addressees of the notices as well, since you, meaning the addressee of the notice, is the most salient keyword. However, close analysis reveals that the addressees of the notices are not always constructed as the target of the threat, but in four of the notices the recipient is constructed as a mediator. In example (1), for instance, the addressee you is constructed as an adviser to the intended target of the threat. In addition, thirteen notices were posted in public spaces and addressed to a wider audience, such as the tenants of an entire parish. Thus, instead of grouping the recipients of the notices, it is more parsimonious to group together the intended targets of the threat, that is, those who will be the beneficiary of the threatened violent process and/or those of whom a demand is made.

(1) so I hope you will advise him to give up the land as soon as opertunity may answer (Barton, 12-09-1867)

The final group that will be distinguished for the purposes of this paper is a group of bystanders for whose benefit the threat is made. This group is constructed as the beneficiary of the threatening process, as the desired outcome is in their interest, but they are not constructed as actors of the threat. The construction of a (group of) bystander(s) occurs in fifty-three notices, which is just over half of the notices under investigation. An example of the construction of this social group is provided in (2), where that poor man is the beneficiary of the 30lbs, but is constructed as a bystander by means of a third-person singular noun phrase.

(2) we serve you with this to remind you of your duty to go and settle with that poor man and pay him down 30lbs (Seery, 4-1-1869)

\subsection{Collectivisation and representation of "Ribbonmen"}

One of the first things to notice is that there are no keywords including the word Ribbon. In fact, a concordance search verifies that this term does not occur at all in the threatening notices, despite the fact that it has been in use since the early nineteenth century (OED, s.v. Ribbonman). In addition, the term was used in songs and literature, so it is likely that the senders of these notices were familiar with it. The only keywords that refer to labels the senders give themselves are Rory, Hill, Captain and oppression. These words are frequently used in combination with each other or with other words as pseudonyms. The most frequent are rory of the hill, enemies to oppression, red rory the mountain war captain, and Captain Rock, though other pseudonyms such as The Brotherhood, Son of Maguire, tiperary boys (on the hill), general tiperary and Captin Buck Shot can be found as well. Most of these pseudonyms were reported to occur in Irish threatening notices from other decades and counties as well (Gibbons 2004), and can thus be said to signal group affiliation among the senders of the notices. In addition, in van Hattum (in progress a) I argue that these pseudonyms carry connotations of nationalist sympathies, sectarian divide and war, which could be seen as positive from a nationalist point of view, but quite negative from the perspective of those in power.

In van Hattum (in progress a), I argue that additional mechanisms through which the authors of the notices construct group affiliation to a perceived Ribbon Society include: a) collectivisation through the significantly high use of first person plural pronouns in comparison to other types of correspondence (see Reisigl and Wodak 2001: 48), and b) the frequent reference to previous outrages, in particular to murders that were deemed to have been committed by the Ribbon Society (see example 3 below). Prentice and Hardie (2009: 47-8) found that in the newsbooks on the 
Glencairn uprising a "discourse of disunity" created an illusion of rivalry in order to divide and conquer. It seems that the senders of the notices are using an opposite strategy, that is the creation of a unity to strengthen the force of the threat.

In terms of categorization of the senders, it seems there are two emerging discourses: one of violence and one of warning. The relevant keywords for the discourse of violence are as, bullet, doom, life, powder, shot, sure and Tarlington, though many more phrases and items fall under this semantic domain, and we can also add drawings of coffins, guns and bullets to this list. The keywords that fall under a discourse of warning are caution, chance, give, if, mark, notice, or, take and warning The two discourses are exemplified in (3), where the sender mentions the consequences of failing to comply with the demands specified and instructs the targets to take it as warning. The violence involves the death of tarlington, who was murdered in Westmeath in 1868 for the dismissal of his herdsman, roary of the hill is to be had, death and judgment will be their doom, and roary and his powdery dry. However, it is interesting to note that all references to violence in this example are nominalisations without a specified actor. In fact, though sentences where an actor, goal and violent process are specified can be found, as in example (4), this occurs only in $4 \%$ of all references to violent acts. It is much more common for the violence to be passivised, nominalised and/or implied, meaning that the senders do not often construct themselves as the actors of a violent process, though they make ample reference to them. In addition, the target of the threat is often foregrounded as an actor or beneficiary in the violent discourse, as in example (5) where the target is the actor of the process prepare your coffin which implies death, or example (6), where the target is constructed as causing the sender to behave in a violent manner through the clause you bring me.

(3) Anotice heir Anny person found going to pay rent will get the Death of tarlington and until their is abatement given dont be a stray of it in the least roary of the hill is to be had any tenant found going pay rent on His[?] estate death and judgment will be their doom I hope you will take it as warning and for your good Fit you all unite you sons of Erin and pay respect to what I say I hope in god we will shortly gain the day boys think on roary and his powder dry (unknown recipient, 3-9-1869)

(4) III shoot yous (McManus, 19-10-1868)

(5) give it up quickly if not you may prepare your coffin (Reily, 10-7-1869)

(6) if you bring me to give you a call you will fall with powder and ball (Cunningham, 16-2186)

Four notices are framed entirely as a direct threat making use of imperative constructions, directive verbs and modals of obligation, as in (7), but all other notices are framed as warnings using lexemes such as (take) caution, (take) heed, mark, (take/give) notice, (take/give) warning and conditional constructions (example 8), or sometimes even friendly advice where the sender follows polite writing conventions and labels him or herself as a friend to the target (example 9). Through framing the notices as warnings or advice, the senders construct themselves in a positive light. The notices frequently point out that they offer the target a choice to do the right thing, and that they do not wish to commit to violence without giving a fair warning, or to put it in the words of the senders $i$ dont want to tak you at any short or do any thing contrery to my Cuntry (Ball, 5-11-1869).

(7) Thomas Moran, I hereby command you to give up the Lands you hold [...] I order you under pain of instant death to give it up [...] Yo must give it up (Moran, 11-1869)

(8) Sir Take Notice that we doo Hereby caution you of Leting any of your Greasing Grass on the property Dysart to that Old selfish Dog or his sons [...] we Request of you Mr Murry to take our counsill (Murry, 18-4-1869) 
(9) My Dear Sir I send you these few lines to let you see that you stood In your own light the day you put away ustis [...] I am a sincere friend I live near where you were born I think bad of you and your father and Mother you did a good turn fore me once and I never forgot it so if you dont have thes people back in a few days you will be sorry (Braddell, 210-1869)

Though the majority of notices are framed as a warning and most of the time the senders do not explicitly construct themselves as the actors of violent processes, they do want to ensure the addressee that they will not shy away from violence if they must, and that they are good at it. The keywords that belong to this type of discourse are sure and as, mostly part of the phrase as sure as which can be combined with a wide range of clauses. Some examples from the collection are, as sure as I am a man your Brains will Be dashed out (Sullivan, 1869), for as shure as the sun shines I will meete you as I met Kelly and Jheseph heer to fore (Hornage, 18-2-1864), and for so shure as this was rote you will come down (Daly, 30-9-1869).

Sure in this sense does not only indicate that they intend to carry out the violent process, but also that the deadly outcome of the process is certain, in other words that they are good at what they do. This strategy of intensification occurs in thirty-six of the notices and can make use of many different expressions, such as I carry good Powder and shot (Somers 27-9-1860), I wont make two bites of a cherry (White 17-11-1868), and I expect not to miss my mark as I am always appointed for making sure (Kelly, 29-5-1870). The last example also has the connotation of organised crime, which is in line with the identities that were constructed for the Ribbonmen in the Westmeath report. Though there are other expressions which are indexical of large-scale organisation, such as reference to received orders or money received for their services, such references only occur in sixteen of the notices.

\subsection{Victimisation of beneficiaries}

The beneficiaries of the threatening notices are frequently referred to with the keywords man, the public, or tenant(s), and, less frequently, as widow or orphan. These nouns are often modified by adjectives relating to vulnerability, such as faithful, honest, industrious, poor, old, and wretched. In addition, they are portrayed as the goal of processes such as deprivation, eviction and robbery. An example of this type of discourse can be found in (10), where the sender reminds the addressee of a poor old man whom the addressee evicted and forced to live on the street.

(10) Dear Sir do you Remember the poor old man that you send out of his holding of land and nocked his little house down and took away the stones and build stone walls with them and did not Care if he died on the road side (Kerrane, 19-3-1870)

In addition to the labels and processes used to construct an identity of victim for the beneficiaries, the notes also make use of lexical and grammaticalised possessive constructions to indicate who the rightful owners of certain plots of land are, which explains the keywords land(s). For example, in (11) the land is identified as belonging to the widow, but the phrase give up suggests that Nicholas is in possession of it now. The land could have been referred to as belonging to the addressee, which would technically be more accurate, or more neutrally to the township or parish in which it is situated, which does occur occasionally as well. However, in $59 \%$ of the cases where the land in question is specified, the land is framed as belonging to a beneficiary who is wrongfully denied access to it (only $10 \%$ is constructed as belonging to the target and the remaining $31 \%$ is neutral in that it refers to a region). These labels and processes mentioned in the previous paragraph, and the possessive constructions mentioned here, are all part of a discourse that foregrounds the vulnerability of the beneficiaries and constructs a "coherent community of victims" (Cope 2001: 
388), while at the same time framing the senders as defenders of the people using a discourse of justice and humanitarianism.

(11) Nicholas i desire you to give up the widows land or if not i will come to see you (Nicholas, 26-10-1871)

\subsection{Criminalisation of targets}

Though it is not surprising to find that the outgroup, or the targets of the threat, is being represented negatively, what is interesting is that the senders make use of the same discourse strategy for the "targets" as the authorities use for the "senders", that is a discourse of criminalisation. The senders of the notices mitigate the threatening force of the notices and the illegitimate nature of their actions through the criminalisation of the targets. This strategy is achieved through labelling, the attribution of bad characteristics and criminal processes and argumentation schemes involving the topoi justice and law and right.

The targets of the notices are constructed as tyrants, making use of the keywords tyranny and tyrant, who take land they do not have a right to, and whose greed makes them value that land more than their life, as demonstrated in examples (12) and (13). Though the targets are never given the value of tyrant in a relational process, the senders do construct them as the possessors of tyriseing ways, or the actors of tyrannical processes. Furthermore, affiliation to the group of tyrants is frequently implied, as in put down every tyreny or tyreniseing men if your class.

(12) i diclear and promised to put down every tyreny or tyreniseing men if your class dont think in your heart or mind that you will Be let to tyrenise on any Poore man that is undere youre lash [...] let you not dare to go on with your damb tyriseing way on any Poor man or tinants [...] i will put down all tyrants (Somers, 27-9-1860)

(13) I deem it my duty to let you know that the [land] you stole be getting scarce in that part of the countray you think you keep it by force [...] if you value land more than your life you must get youre wish (White, 7-11-1868)

Other labels that do not appear frequently enough to come up as keywords, but do reinforce the criminalisation of targets include: interloping creaters [creatures], land canters, land puffers, meadow takers, and neroes, who are accused of mingin outside you own land, robbery, treachery and commit fullany [felony] and kill. Sometimes the targets are even dehumanised through labels such as beast, dog, devil, landshark, poisonous weed, two-headed monster, tyrant tiger, and serpent fiend who proul over the poor beneficiaries. More general negative labels assigned to the targets are bad, bigot, covetous, coward, curse(d), damned, and scally who do evil, damage, and harm.

In addition, a concordance search for the keywords laws and public revealed that they are frequently used by the senders in topoi of law and right and humanitarianism in order to justify and legitimise their actions. According to Wodak (2001: 73), the topos of law and right is invoked when the argumentation involves laws or otherwise codified norms that forbid or enforce certain actions. In example (14), for instance, the sender makes the addressee aware of laws and cautions him not to violate them. By modifying laws with laid down in the publick notices the sender implies that those laws have been codified and disseminated to the public. The sender continues with the theme of justice, suggesting that the laws were created to ensure equality among the poor as well as the rich and then returns to law and right by saying that the laws are made and will be carried out, thus enforcing these laws. Other lexical items that belong to this topos include allow, authority, doctrine, guilty, judgement, law, (tenant) right, rule, sentence, trial, unlawful and violate. 
(14) for your own safety we caution you to have nothing to do Whatever in the taking of grass farms which must be let to the publick if you or any one else violate the laws laid down in the publick notices you shall receive the Reward [...] every person must have an equal chance of getting grass for His stock the poor as well as the rich [...] the laws are made and will be carried out effectually [...] We Remain enemys To oppression (Reilly, 22-21869)

In addition, the topos of humanitarianism, which concerns actions that go against humanitarian convictions or values (Wodak 2001: 73), is also frequently invoked through means of the keyword public, which collocates with opinion and/or against to indicate that the people of Ireland do not agree with the actions of the targets, as in example (15) where the sender warns the addressee that his acts caused for publich Opinion to go agan you. The example further invokes the theme of law and right by referring to the enforcement of laws through the judicial system with the lexical items tried, guilty and sentence. Other lexical items belonging to the topos humanitarianism include the keyword oppression and the lexical phrases against the country, equal, fair (play/rent/valuation), just, rackrent and right.

(15) a sir publick Opinion is gone agane you you are tride and found gilty and your sintence is short (Tarlington, 16-11-1868)

Furthermore, as part of the topoi of humanitarianism and justice, the senders frequently include religious expressions to demonstrate that God is on their side and to make their actions more justifiable, similar to the strategies used in the newsbooks on the Glencairn uprising (Prentice and Hardie 2009: 44). In example (16), the sender informs the addressee that the time of justice has arrived and that he obtained the land through the actions of his uncle who betrayed the Roman Church. Finally, the sender claims that the Heavens have charged him with the task of bringing the addressee to justice. Most of these religious expressions make reference to Christianity in general and do not seem to serve the function of creating a Roman Catholic ingroup and a Protestant outgroup. The only examples that could be interpreted in this manner are (16), where sold his seat in the church of Rome at least suggests that the uncle is not a Roman Catholic and thus belongs to an outgroup, and (17) where the label organgeman is indexical of the Protestant religion. Furthermore, though unfortunately the quality of the photograph was not good enough to decipher the entire sentence, example (18) at least seems to suggest that the sender believes the target to be a Catholic and thus belongs to a Catholic ingroup. However, even belonging to the ingroup will not save you. Within the context of the time it is impossible to rule out religious sectarianism as a motivation for selecting particular targets, and that general references to Christian religion refer to the ingroup religion. Nevertheless, the senders do not seem to foreground the sectarian divide and instead seem to focus on the criminal and inhumane actions of the targets.

(16) Well Patrick as the time of justice has arrived I demand of you them six acres that you hold at the back of the widow besides they are not your right now [...] your uncle sold his seat in the church of Rome to optain ground for you's [...] For the case is in my hands by Heavens your life I will have (Byrne, 1869)

(17) hornage wanted to put a tyrrellspass orange man in their please but the peple resisted his bigatory (Barton, 12-9-1867)

(18) Teak Notice that [?] of Catholic will not save you (Council, 4-1-1871)

\section{Discussion}


The analysis of the threatening notices revealed that those deemed to be Ribbonmen by the authorities construct a positive representation of their social group through the following strategies: a) the creation of an organised and competent ingroup who are fair and just, and only commit violent acts out of necessity; $b$ ) the creation of a social group of beneficiaries in whose interest the senders act, alongside the victimisation of this particular social group; $c$ ) the creation of a social group of targets of the threat who are criminalised and sometimes even dehumanised; and d) the justification and legitimisation of the acts of the senders through topoi of law and right, and justice and humanitarianism. These strategies tend to portray the Ribbonmen and the beneficiaries in a positive light, while the targets on the "them" side are portrayed more negatively, similar to the English and the Scots in Prentice and Hardie (2009) and other studies of contemporary war reportage (e.g. Baker and McEnery 2005). However, in the case of the threatening notices it is not those in power, that is the government or media, who construct a positive ingroup for themselves and marginalise the outgroup by presenting them in a negative light. Instead, the marginalised group itself, that is the senders of the notices, use rhetorical techniques like those found in the Westmeath report (House of Commons 1871) to criminalise the outgroup and legitimise their own actions.

The analysis has shown that the sending of the notices involved a pervasive element of legitimisation. The depiction of the targets, frequently landlords and agents, as tyrannical, criminal and unjust functions to establish the moral superiority of the senders of the notices over them. This rhetoric is reminiscent of the notion of the moral economy of the crowd popularised by Thompson (1971; 1991) and extended outside the context of eighteenth-century English food riots to, for example, Irish food riots between 1817 and 1845 (Cunningham 2010), Irish militia disturbances in 1793 (Bartlett 1983), and the English swing riots of 1830 (Jones 2007). What these events have in common is that these disturbances involved collective negotiation between the lower classes and those in power. The objective of these negotiations was to expose breaches of traditional customs and rights and a moral economy based on justice and fairness, and force the elite to comply with these unwritten social norms. If the senders only aim in writing the notices was to intimidate the targets, then there would be no need for such strategies of positive self and negative other representation. Instead, the sending of threatening notices in the eighteenth and nineteenth centuries has sometimes been characterised as "one of the weapons of the weak" (Jackson 2016), "a form of social protest" (Thompson 1975), and "a means of bargaining with local power holders by actors and communities without access to formal political space" (Whelehan 2012: 8).

Above I argue that contrary to most CDA studies, this paper analyses the dominant ideologies in the discourse of marginalised groups, rather than the public discourse produced by the elite. However, I suggest that these notices still constitute a form of public discourse. The survival of envelopes indicates that roughly half of the notices were sent through the postal system, but a substantial proportion had been nailed to doors or gates (van Hattum in progress b), and could be read by anyone. In addition, multiple or collective addressees such as Poloughter Tenants, headers such as Public Notice, warnings not to take the notice down and instructions to pass on the notice to others suggest that the senders expected the notices to reach a wider audience. Finally, it is likely that the senders were aware that the notices would be forwarded to the authorities, as a couple of senders deliberately modified their handwriting to avoid identification (van Hattum in progress. b). Thus, these notices provided the senders with an audience that not only consisted of their intended targets, but also included their peers and the authorities, and thus constituted a form a public discourse through which to disseminate their ideology of a moral economy and tenant and labour rights as a secondary aim, alongside its primary goal to intimidate the target. 
Even though I do believe that many of the notices made use of negative other representation and discourses of justice and law and right to spread their ideas, I hesitate to make this claim for all notices under investigation. Firstly, there were a handful of notices that did not construct a positive self- or negative other-image, like the one in example (19).

$$
\begin{aligned}
& \text { Chaley Flanagan } \\
& \text { take notice by this } \\
& \text { give up mowing oats } \\
& \text { and of this does not } \\
& \text { do i will call } \\
& \text { to see you and leave } \\
& \text { you in a way you wont } \\
& \text { be able (Flanagan, 8-1869) }
\end{aligned}
$$

Second, the repeated use of "Ribbon" rhetoric in these notices created the image of a unified society, and it is possible that individuals seeking personal gain made use of this rhetoric to reinforce the threat, rather than all senders indeed belonging to a uniform social group. Many of these notices were public discourse, and it is likely that most people living in Westmeath in the 1860s had at one time or another been exposed to such notices and thus were aware of the rhetoric used in them. In addition, the Ribbon society instilled fear into the minds of their targets specifically, and of the authorities more generally.

To exemplify the possibility of mimicking the Ribbon rhetoric, I would like to draw attention to a notice that was not part of the collection, but produced in the same county in the same decade. This notice was sent to the authorities along with a personal letter written by Patrick Bannon from Birr King's County. The personal letter was written in a similar hand, on the same type of paper, and concerned the same topic as the threatening notice (i.e., money owed to Patrick Bannon by Colonel Bernard). The personal letter was signed by Patrick Bannon and written in the first person singular. Patrick constructs himself as a victim who believes the addressee, Colonel Bernard, owes him money for his labours, but is generally speaking very polite and obliging and would be for ever thankful to yourself if he sent him his money. The anonymous threatening notice, on the other hand, is written entirely in the first person plural, and frames Patrick Bannon as a third person, though he is likely the author of the letter. It presents Patrick Bannon as a poor, but merciful person who begged the senders not to take action, but the senders have the same oppertunety and the same nerve and the corrage to cot the tirent down, whereas Colonel Bernard is constructed as a robber and a tyrant. Thus, it seems that Bannon is consciously making use of a Ribbon rhetoric to reinforce the threat of the notice, though the notice itself seem to have been sent to settle a personal dispute and does not form part of the enforcement of a moral economy.

At the start of this paper, I argued that the authorities constructed Ribbonmen as members of an illegal and criminal organisation that terrorised the population of Ireland. A CDA of a collection of threatening notices written by members of this supposed organisation revealed that the way the senders of the notices constructed their own identities was quite different. Most of the notices indeed constructed the sender's identity as members of an organisation and victimise the labouring classes of Westmeath, but discourses similar to those found in the Westmeath report were used to criminalise the elites, that is the targets of the threat, rather than the Ribbon society, and to justify and legitimise their own actions in line with their traditional norms and values and the notion of a moral economy. This confirms Thompson's (1973) idea that, in addition to sending threatening notices as tools of intimidation in pursuit of a private grievance, the labouring classes made use of 
this tool as a form of social protest against an elite that supports the shift of a moral economy towards a free-market economy.

\section{References}

Auer, Anita, Tony Fairman, Moragh Gordon, Mikko Laitinen \& Marije van Hattum. under construction. Letters of artisans and the labouring poor (LALP). The University of Manchester, Université de Lausanne, University of Eastern Finland and Utrecht University. https://lalpcorpus.wordpress.com/

Baker, Paul. 2010. Sociolinguistics and Corpus Linguistics. Edinburgh: Edinburgh University Press.

Baker, Paul \& Tony McEnery. 2005. A corpus-based approach to discourses of refugees and asylum seekers in UN and newspaper texts. Journal of Language and Politics 4(2). 197-225.

Bartlett, Thomas. 1983. An end to moral economy: The Irish militia disturbances of 1793. Past \& Present 99. 41-64.

Beames, Michael R. 1982. The Ribbon Societies: Lower-class nationalism in pre-famine Ireland. Past \& present 97. 128-143.

Comerford, Vincent. 1989a. Ireland 1850 - 70: Post-famine and mid-Victorian. In William E. Vaughan (ed.), A New History of Ireland. Volume V. Ireland under the Union, I. 1870-70, 372-395. Oxford: Clarendon Press.

Comerford, Vincent. 1989b. Conspiring brotherhoods and contending elites, 1857-63. In William E. Vaughan (ed.), A New History of Ireland. Volume V. Ireland under the Union, I. 1870-70, 415-430. Oxford: Clarendon Press.

Comerford, Vincent. 1989c. Gladstone's first Irish enterprise, 1864-70. In William E. Vaughan (ed.), A New History of Ireland. Volume V. Ireland under the Union, I. 1870-70, 431-450. Oxford: Clarendon Press.

Cunningham, John. 2010. "Compelled to their bad acts by hunger": Three Irish Urban Crowds, 18171845. Éire-Ireland 45. 128-15.

Fairman, Tony. 2007. 'Lower-order' letters, schooling and the English language, 1795-1834. In Stephan Elspass et al. (eds.) Germanic language histories 'from below' (1700-2000), 31-44. Berlin, New York: de Gruyter.

Garvin, Tom. 1982. Defenders, Ribbonmen and others: underground political networks in pre-famine Ireland. Past \& Present 96. 133-155.

Gibbons, Stephen R. 2004. Captain Rock, Night Errant. The Threatening Letters of Pre-Famine Ireland, 1801-1845. Dublin: Four Courts Press.

Van Hattum, Marije. In progress a. "I am roary on the hill": Identity-construction in $19^{\text {th }}$-century Irish English threatening notices. Submitted to Journal of Historical Pragmatics, 15-8-2016.

Van Hattum, Marije. In progress b. "think on roary and his powder dry": Nineteenth-century Irish English threatening notices from a genre and register perspective. Submitted to Text \& Talk 511-2016.

House of Commons. 1871. Report from the select committee on Westmeath, \&c. (unlawful combinations); together with the proceedings of the committee, minutes of evidence, and appendix. House of Commons Parliamentary Papers Online.

House of Lords. 1871. The House of Lords Official Report. Series 3. Vol 205. Collection 1768. http://hansard.millbanksystems.com/lords/1871/apr/27/protection-of-life-and-property-in (accessed 14 December 2015)

Jackson, Leon. 2016. The Spider and the Dumpling: Threatening Letters in Nineteenth-Century America. In Celeste-Marie Bernier, Judie Newman \& Matthew Peters (eds.), The Edinburgh Companion to Nineteenth-Century American Letters and Letter-writing, 152-168. Edinburgh: Edinburgh University Press. 
Jones, Peter. 2007. Swing, Speenhamland and rural relations: the 'moral economy' of the English crowd in the nineteenth century. Social History 32(3). 271-290.

MacLeod, Nicci. 2012. Rogues, villaines and basic trulls: constructing the 'other' in the 1641 depositions. In Eamon Darcy, Annaleigh Margery \& Elaine Murphy (eds.), The 1641 Depositions and the Irish Rebellion, 113-127. Abingdon: Pickering \& Chatto.

MacLeod, Nicci \& Barbara Fennel. 2012. Lexico-grammatical portraits of vulnerable women in war: the 1641 depositions. Journal of Historical Pragmatics 13(2). 259-290.

Malcolm, Elizabeth. 2002. Investigating the "Machinery of Murder": Irish Detectives and Agrarian Outrages. 1847-70. New Hibernia Review 6(3). 73-91.

Murray, A. C. 1986. Agrarian Violence and Nationalism in Nineteenth-Century Ireland: The Myth of Ribbonism. Irish Economic and Social History 13. 56-73.

Prentice, Sheryl \& Andrew Hardie. 2009. Empowerment and disempowerment in the Glencairn uprising: A corpus-based critical analysis of Early Modern English news discourse. Journal of Historical Pragmatics 10(1). 23-55.

Reisigl, Martin \& Ruth Wodak. 2001. Discourse and Discrimination: Rhetorics of Racism and Antisemitism. London: Routledge.

Thompson, E. P. 1971. The moral economy of the English crowd in the eighteenth century. Past \& Present 50. 76-136.

Thompson, E. P. 1975. The Crime of Anonymity. In Douglas Hay, Peter Linebaugh, John G. Rule, E. P. Thompson \& Carl Winslow (eds.), Albion's Fatal Tree. Crime and Society in Eighteenth-Century England, 255-344. London: Allen Lane.

Thompson, E. P. 1991. Customs in Common. London: Merlin Press.

Whelehan, Niall. 2012. Labour and Agrarian Violence in the Irish Midlands, 1850-1870. Saothar 37. 717.

Wodak, Ruth. 2001. The discourse-historical approach. In Ruth Wodak \& Michael Meyer (eds), Methods of Critical Discourse Analysis, 63-94. London: Sage. 